\title{
Recombinant bacteriophage LysKB317 endolysin mitigates Lactobacillus infection of corn mash fermentations
}

\author{
Shao-Yeh Lu' ${ }^{1}$, Kenneth M. Bischoff ${ }^{1}$, Joseph O. Rich ${ }^{1,2}$, Siqing Liu ${ }^{1}$ and Christopher D. Skory ${ }^{1 *}$ (1)
}

\begin{abstract}
Background: Commercial ethanol fermentation facilities traditionally rely on antibiotics for bacterial contamination control. Here we demonstrate an alternative approach to treat contamination using a novel peptidoglycan hydrolase (LysKB317) isolated from a bacteriophage, EcoSau. This endolysin was specially selected against Lactobacillus strains that were isolated as contaminants from a fuel ethanol plant. The LysKB317 gene was recombinantly expressed in Escherichia coli as a $33 \mathrm{kDa}$ purified enzyme.

Results: In turbidity reduction assays, the recombinant enzyme was subjected to a panel of 32 bacterial strains and was active against 28 bacterial strains representing 1 species of Acetobacter, 8 species of Lactobacillus, 1 species of Pediococcus, 3 species of Streptococcus, and 1 species of Weissella. The activity of LysKB317 was optimal around pH 6, but it has broad activity and stability from $\mathrm{pH} 4.5-7.5$ up to at least $48 \mathrm{~h}$. Maximum activity was observed at $50^{\circ} \mathrm{C}$ up to at least $72 \mathrm{~h}$. In addition, LysKB317 was stable in 30\% ethanol up to at least $72 \mathrm{~h}$. In experimentally infected corn mash fermentations, $1 \mu \mathrm{M}$ endolysin reduced bacterial load by 3-log fold change, while $0.01 \mu \mathrm{M}$ reduced bacteria by 2 -log fold change. Concentration of fermentation products (ethanol, residual glucose, lactic acid, and acetic acids) for infected cultures treated with $\geq 0.01 \mu \mathrm{M}$ LysKB317 was similar to uncontaminated controls.

Conclusion: Exogenously added LysKB317 endolysin is functional in conditions typically found in fuel ethanol fermentations tanks and may be developed as an alternative to antibiotics for contamination control during fuel ethanol fermentations.
\end{abstract}

Keywords: Phage endolysin, Contamination, Fuel ethanol, Lactobacillus, Antimicrobial

\section{Background}

Endolysins are peptidoglycan hydrolase enzymes (also known as phage lysins) produced by bacteriophages to enzymatically degrade host bacterium cell wall from within to release progeny virions at the end of lytic multiplication cycle [1]. Due to endolysins' antibacterial

\footnotetext{
*Correspondence: chris.skory@usda.gov

${ }^{1}$ Renewable Product Technology Research Unit, National Center for Agricultural Utilization Research, Agricultural Research Service, U.S. Department of Agriculture, 1815 North University Street, Peoria, IL 61604-3902, USA

Full list of author information is available at the end of the article
}

activity, they are considered potential alternatives to antibiotics $[2,3]$.

The fuel ethanol industry in the United States has experienced a tremendous growth over past decade from 110 plants ( 6.5 billion gallons per year) in 2007 to 200 plants in 2017 with production capacity approaching 16 billion gallons per year $[4,5]$. An estimated production capacity for fuel ethanol would need to reach 60 billion gallons per year by 2030 to meet the proposed US Energy Independence and Security Act (EISA) of 2007, Renewable Fuel Standard (RFS) mandates, and goal set by the environmental protection agency (EPA) and other states to increase higher blend of ethanol in gasoline [6-8]. 
However, commercial ethanol fuel facilities rarely perform fermentations under aseptic conditions $[9,10]$. Fermentation tanks in ethanol production are constantly contaminated with a wide variety of microbes that can cause chronic and acute contaminations in commercial biorefineries [11]. These strains cause both chronic and acute infections in commercial biorefineries and can significantly reduce the level of ethanol production $[4$, $9,10,12,13]$. Potential sources of microbial contamination (bacteria, fungi, and wild yeast) can be found in raw materials such as corn, corn mash, and process water, although through the liquefaction process they appeared to be inactivated $[9,13-15]$. Acute contamination often occurs unpredictably and can lead to a costly shutdown of facilities [16]. It is generally believed that lactic acid bacteria (LAB), and predominantly species of Lactobacillus, are the primary bacterial contaminants found in fuel ethanol fermentation facilities $[17,18]$. In addition to competition of nutrients and substrates with fermenting yeast, bacterial contaminants produced undesirable byproducts such as acetic and lactic acids can inhibit yeast growth $[9,19]$. The presence of Lactobacillus can cause "stuck fermentations" and decrease yields of ethanol production as Lactobacillus spp. compete for resources and negatively impact the health of Saccharomyces sp. $[4,16-18,20]$. The solution to combat contamination in the United States has traditionally relied on the usage of antibiotics such as erythromycin, penicillin, and virginiamycin [21]. Concerns over long-term excessive usage of antibiotics are believed to contribute to the emergence of antibiotic resistant bacteria and remains controversial in the ethanol industry [22, 23]. Alternative strategies such as the deployment of all-natural proteinaceous antimicrobial control agents such as endolysin are warranted.

In this study, we described the application of a novel recombinant peptidoglycan hydrolase (endolysin) LysKB317 derived from Lactobacillus bacteriophage vB_LfeS_EcoSau (abbreviated as EcoSau); isolated from commercial sauerkraut) to inhibit the growth of lactic acid bacteria known to contaminate ethanol fermentation facilities [24]. This endolysin derived from EcoSau was designated to LysKB317 in honor of Dr. Kenneth Bischoff. We demonstrated the effectiveness of exogenously added endolysin LysKB317 with predicted GH25 muramidase activity to a panel of Gram-positive bacterial species such as Lactobacilli. LysKB317 showed a robust antibacterial activity against eight species of $L a c$ tobacillus, including those that are problematic in the fuel ethanol industry. In addition, LysKB317 confirmed some activity against bacterial species such as Acetobacter pomorum, Pediococcus spp. Streptococcus spp., and Weissella confusa isolated from commercial biorefineries.
We determined the activity profile of LysKB317 under fermentation conditions, and with extended exposure to various $\mathrm{pH}$, temperature, and percent ethanol. The robustness of LysKB317 was demonstrated in an experimentally infected corn mash fermentation to treat against Lactobacillus fermentum contamination and restored yield of ethanol fermentation by $S$. cerevisiae. Overall results showed the potential of endolysin LysKB317 as an alternative to conventional antibiotics to control contamination for the fuel ethanol industry.

\section{Results}

Lytic activity of purified endolysin LysKB317 confirmed

We were able to express and purify the phage lytic protein in recombinant $E$. coli as the $\mathrm{N}$-terminus $6 \times$ Histagged LysKB317 (Fig. 1a; GenBank accession number AIY32273.1). The endolysin consists of a glucohydrolase family 25 (GH25) muramidase-superfamily domain and a cell wall binding SH3b homologue domain (Fig. 1a). Based on blast search and homologous to protein sequences analyses with known functions, the predicted muramidase activity in LysKB317 is thought to cleave $\beta$ - $(1,4)$-glycosidic bond of the peptidoglycan $N$-acetylglucosamine- $N$-acetylmuramic acid (NAG-NAM) linkages (Fig. 1b; [25, 26]) The SDS-PAGE and western blot analysis were performed on the nickel-NTA column purified protein, which produced a single prominent band for LysKB317 with the predicted molecular mass of $33.8 \mathrm{kDa}$ (Fig. 2a and Additional file 1: Figure S1). Spot plate assay (using MRS agar plate incorporated $1 \mathrm{~mL}$ of live $L$. fermentum $0315-25\left(\mathrm{OD}_{600}=0.8\right)$ in $0.7 \%$ soft top agar) demonstrated exolytic activity after spotting of $5 \mu \mathrm{L}$ LysKB317 (either expressed whole cell lysate supernatant or purified LysKB317; Fig. 3). Under visual observation, the zone of clearing in both whole cell lysate supernatant or purified LysKB317 samples were significantly more pronounced compared to those of LysA (minimum activity against $L$. fermentum 0315-25; [4]), and lysozyme (positive control) confirming the exolytic activity of the enzyme. Zymogram analysis was performed with copolymerized L. fermentum 0605-B44 into the gel matrix. Single translucent bands in the same size region as the predicted LysKB317 were clearly visible for whole cell lysate, soluble fraction, and purified enzyme of LysKB317 from the expression host E. coli (Fig. 2b).

\section{The LysKB317 lyses a range of Lactobacillus species}

Purified endolysin LysKB317 was tested using a turbidity reduction assay against several bacterial species (Table 1) isolated from commercial fuel ethanol fermentation plant (Fig. 4). LysKB317 had a strong lytic activity (>100 $\mathrm{OD}_{600} / \mathrm{min} / \mu \mathrm{M}$ enzyme; Fig. 4$)$ against all of the $L$. fermentum strains tested in the panel (Table 1 ). 
a
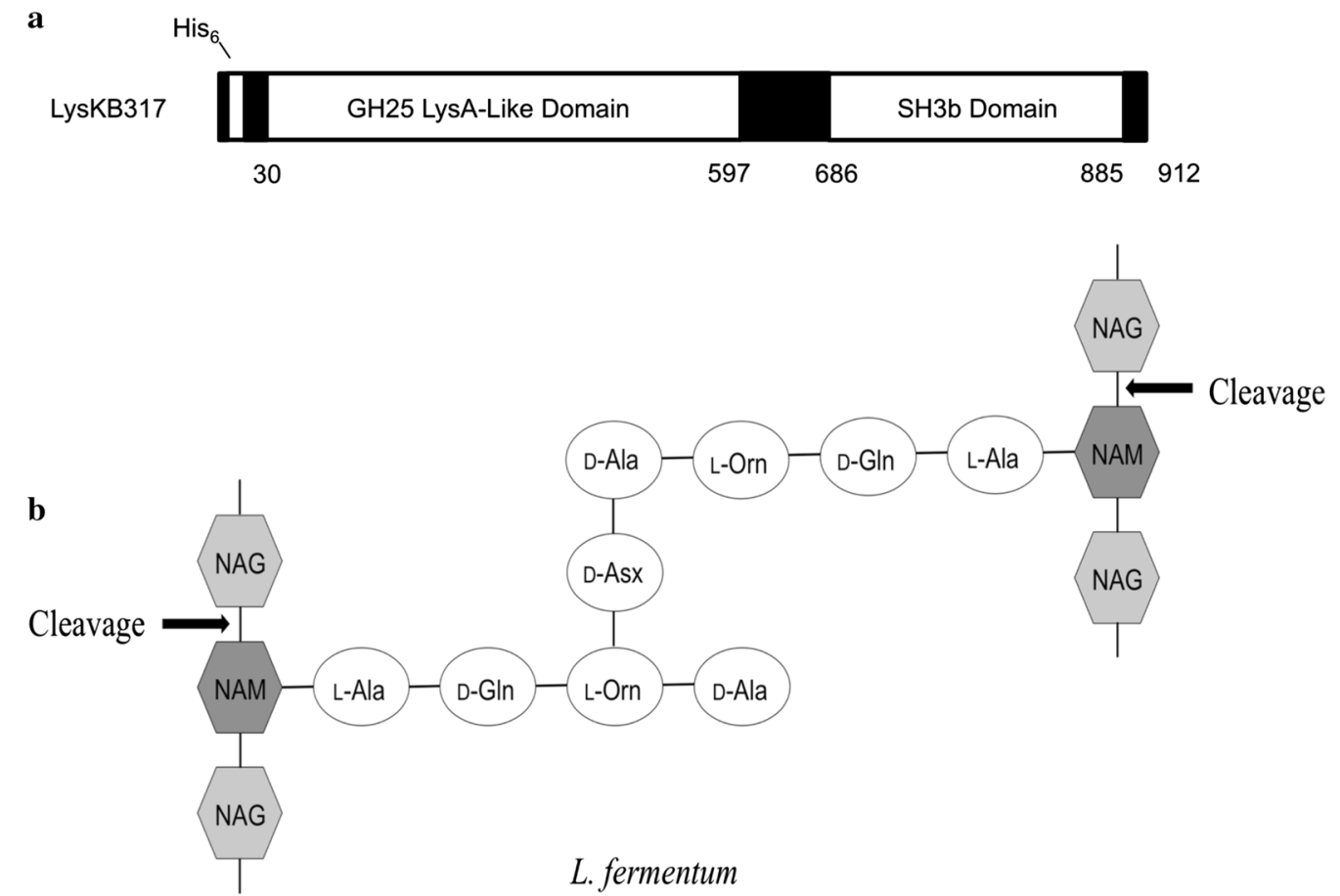

Fig. 1 Schematic representation of LysKB317 domain structures and putative endolysin catalytic site on peptidoglycan of L. fermentum. a The LysKB317 is a recombinant (912 bp) 6 × His-tag phage lytic protein (33.8 kDa). The endolysin architecture (not to scale) consist of a fused $\mathrm{N}$-terminal $6 \times$ His-tag, glycosidase family 25 (GH25) lysin A-like enzymatic activity domain and a cell wall binding SH3b homologue domain based on amino acid homologies and conserved domains (catalytic and cell-wall binding) prediction data base. (GenBank accession number AlY32273.1). b The predicted LysKB317 catalytic site against Lactobacillus fermentum repeated peptidoglycan structure (modified from [4, 25, 26]) based on amino acid homologies to other biochemically characterized lytic enzymes [36]. D-Asx stands for D-Asp or amidated D-Asp (D-Asn [53])

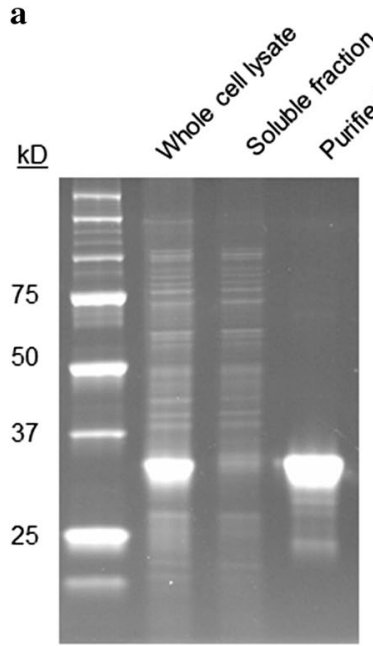

SDS-PAGE
$\underline{\mathrm{kD}}$

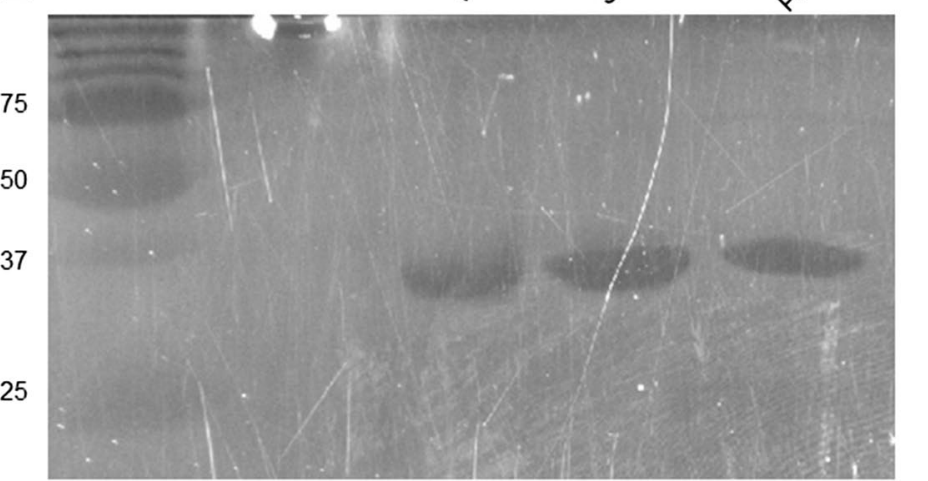

Zymogram

Fig. 2 SDS-PAGE and recombinant LysKB317 endolysin zymogram assay. Whole cell lysate of overnight induced E. coli strain E. cloni 10G/ pRham N-His Kan::LysKB317, soluble fraction from the whole cell lysate $(2.5 \mu \mathrm{g})$ and purified LysKB317 endolysin $(0.25 \mu \mathrm{g})$ were run on a $15 \%$ SDS-polyacrylamide gel. a Left panel: LabSafe Gel Blue stained gel. b Right panel: Zymogram activity assay. The gel contained bacterial cells of $L$. fermentum 0605-B44 polymerized within the gel matrix. Following electrophoresis, the gel was washed with deionized water for $1 \mathrm{~h}$, then incubated in 1\% Triton X-114, $50 \mathrm{mM}$ Tris, pH 5.5 buffer until zones of clearing were visible (indicated hydrolase activity of LysKB317) 


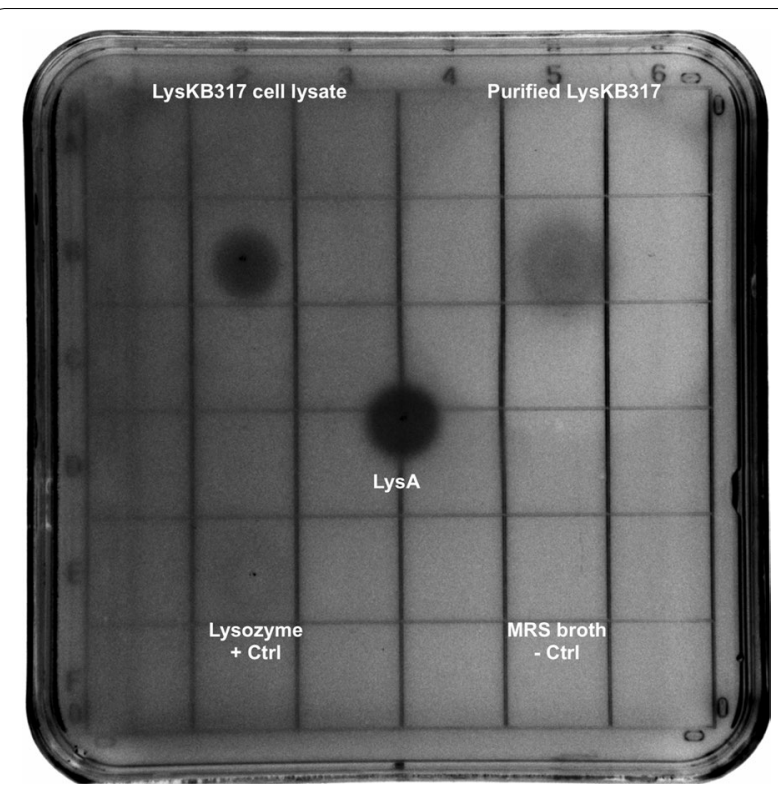

Fig. 3 Spot plate assay of LysKB317 showed exolytic activity against L. fermentum 0315-25. Purified LysKB317 was spot onto an MRS agar plate that contained a soft top $0.7 \%$ agar with L. fermentum $0315-25$ $\left(\mathrm{OD}_{600}=0.8 ; 1 \mathrm{~mL}\right)$. Whole cell lysate expressing LysKB317 (5 $\mathrm{LL} ; \mathrm{E}$. cloni 10G/pRham N-His kan::LysKB317; Table 1), purified LysA2 (5 $\mu \mathrm{L}$; negative control; [54]), $20 \mu \mathrm{g} / \mathrm{mL}$ lysozyme (positive control), and $5 \mu \mathrm{L}$ of MRS broth (negative control) were spotted on to plate and allow to air dry before incubating at $37^{\circ} \mathrm{C}$ until zone of clearance can be visualized

When other lactic acid bacteria species were included in the tests (Fig. 4), approximately $87 \%$ of the Lactobacillus spp. tested from the panel were susceptible to LysKB317 (Fig. 4). Furthermore, the endolysin showed lytic activity against bacterial species other than Lactobacilli such as Weissella confuse, Acetobacter pomorum, Pediococcus acidilactici, Staphylococcus lugdunensis and two species of Streptococcus (Fig. 4). However, bacterial species including Enterococcus faecium, L. amylovorus, and $L$. brevis presented minimum to none exolytic activity by the LysKB317.

\section{LysKB317 endolysin remains active in the fermentation environment}

To examine the enzymatic activity of endolysin LysKB317 under typical fuel ethanol fermentation conditions, the enzyme was tested under a range of $\mathrm{pH}$, temperature, and ethanol concentration over time using turbidity reduction assays. The optimal $\mathrm{pH}$ for LysKB317 was achieved at pH 6 and it was stable for up to at least $48 \mathrm{~h}$ (Fig. 5). In addition, the enzyme was functionally stable in a range of $\mathrm{pH} 4.5-7.5$ up to at least $48 \mathrm{~h}$, but the lytic activity of the endolysin at $\mathrm{pH} 4$ was compromised. Thermostability of the enzyme was observed from $4{ }^{\circ} \mathrm{C}$ to
$50{ }^{\circ} \mathrm{C}$ for at least $72 \mathrm{~h}$ (Fig. 6). At $60{ }^{\circ} \mathrm{C}$, thermal stability of the enzyme started to deteriorate after $41 \mathrm{~h}$ of incubation and the lytic activity was abolished by $72 \mathrm{~h}$. Minimal to no lytic activity was observed at $95{ }^{\circ} \mathrm{C}$ regardless of the time LysKB317 was incubated (Fig. 6). The presence of ethanol at or below $5 \%$, did not have a significant impact on the lytic activity of the endolysin regardless of incubation time (0-72 h; Fig. 7). LysKB317 remained active upon exposure of ethanol concentration up to $30 \%$, although activity was approximately $45-54 \%$ less than samples without added ethanol (Fig. 7).

\section{LysKB317 reduces Lactobacillus in a model fermentation flask}

As described previously [4], we emulated fermentations using corn mash solids to test the effects on LysKB317 (Fig. 8). In experimentally infected corn mash fermentations, the addition of endolysin at $1 \mu \mathrm{M}$ reduced bacterial load by approximately 3-log fold over time (black circle) compared to the challenged control fermentation (gray triangle), which rose above $9-\log \mathrm{CFU} / \mathrm{mL}$. Uninfected corn mash fermentations (negative control) and LysKB317-treated fermentations without infection (negative control) did not have detectable bacterial load over 3-log CFU/mL (limit of detection) were not included in the graph.

\section{Fermentation products of infected but LysKB317 treated were similar to those of uninfected controls}

In our model bacterial infected flask yeast fermentation runs, the highest concentration of LysKB317 (10,000 nM $\equiv 330 \mu \mathrm{g} / \mathrm{mL}$ ) reduced bacterial load by 4-log fold CFU/ $\mathrm{mL}$ change, while $100 \mathrm{nM}(3.3 \mu \mathrm{g} / \mathrm{mL})$ was able to reduce bacteria load by approximately 2-log fold (Table 2). The bacterial $L$. fermentum fermentation byproducts, such as lactic acid and acetic acid, which are known to inhibit S. cerevisiae and reduce ethanol yields were reduced significantly with the addition of LysKB317. Lactic acid was reduced more than $20 \%$ from $19.8 \mathrm{~g} / \mathrm{L}$ to $15.4 \mathrm{~g} / \mathrm{L}$, while acetic acid decreased by more than $70 \%$ from $3.6 \mathrm{~g} / \mathrm{L}$ to $1.0 \mathrm{~g} / \mathrm{L}$. The glucose utilization by $S$. cerevisiae after LysKB317 treatment $(10,000 \mathrm{nM})$ in L. fermentum infected corn mash compared to uninfected corn mash had an over $98 \%$ improvement (from $38.9 \mathrm{~g} / \mathrm{mL}$ glucose prior to treatment down to $0.7 \mathrm{~g} / \mathrm{mL}$ glucose after endolysin treatment). End concentration of ethanol after fermentation had increased to $21.3 \mathrm{~g} / \mathrm{mL}(\sim 22 \%$ increase). The LysKB317-treated flask fermentation resulted comparable levels of glucose utilization and ethanol production when compared with that of uninfected flask fermentation controls. 
Table 1 Bacteria and yeast strains used in this study

\begin{tabular}{|c|c|c|}
\hline Bacteria and yeast & Relevant genotype/phenotype ${ }^{a, b}$ & Reference or source \\
\hline \multicolumn{3}{|l|}{ Escherichia coli } \\
\hline E. cloni 10G & $\begin{array}{c}\text { mcrA } \triangle(\text { mrr-hsdRMS-mcrBC) endA1 recA1 } \varphi 80 \mathrm{~d} / a c Z \Delta M 15 \Delta l a c X 74 \\
\left.\text { araD139 } \triangle \text { (ara,leu)7697 galU galK rpsL (Str }{ }^{R}\right) \text { nupG } \lambda^{-} \text {tonA }\end{array}$ & Lucigen Co \\
\hline E. cloni 10G/pUC57::LysKB317 & Amp $^{R}$, containing LysKB317 gene & GenScript, This study \\
\hline E. cloni 10G/pRham N-His Kan::LysKB317 & $\mathrm{Kan}^{\mathrm{R}}$, containing LysKB317 gene & This study \\
\hline $\mathrm{BL} 21(\mathrm{DE} 3)$ & $\mathrm{F}^{-}$ompT hsdSB (rB-mB-) gal dcm (DE3) & Invitrogen \\
\hline BL21(DE3)/pET21a::LysA & $A_{m p}{ }^{R}$, containing Lys A gene & [4] \\
\hline \multicolumn{3}{|l|}{ Acetobacter pomorum } \\
\hline 150316 F1.18 & Wildtype & This study \\
\hline \multicolumn{3}{|l|}{ Enterococcus faecium } \\
\hline B-41204 & Wildtype & NRRL \\
\hline $1410-7.24$ & Wildtype & NRRL \\
\hline \multicolumn{3}{|l|}{ Lactobacillus amylovorus } \\
\hline 0315-7B & Wildtype & [51] \\
\hline 150316 F 2.23 & Wildtype & This Study \\
\hline \multicolumn{3}{|l|}{ Lactobacillus brevis } \\
\hline $0605-48$ & Wildtype & {$[4]$} \\
\hline $1410-6.6$ & Wildtype & This study \\
\hline \multicolumn{3}{|l|}{ Lactobacillus casei } \\
\hline 0910097.25 & Wildtype & This study \\
\hline $1410-5.41$ & Wildtype & This study \\
\hline \multicolumn{3}{|l|}{ Lactobacillus delbrueckii } \\
\hline B-1924 & Wildtype & NRRL \\
\hline B-4525 & Wildtype & NRRL \\
\hline B-763 & Wildtype & NRRL \\
\hline \multicolumn{3}{|l|}{ Lactobacillus fermentum } \\
\hline B-1840 & Wildtype & NRRL \\
\hline B-1932 & Wildtype & NRRL \\
\hline 0315-1 & Wildtype & {$[51,52]$} \\
\hline 0315-25 & Wildtype & {$[4,51]$} \\
\hline 0605-B44 & Wildtype & {$[4]$} \\
\hline $091009-8.21$ & Wildtype & This study \\
\hline $1101-7.13$ & Wildtype & This study \\
\hline $1410-1.1$ & Wildtype & This study \\
\hline $1502-8.10$ & Wildtype & This study \\
\hline \multicolumn{3}{|l|}{ Lactobacillus johnsonii } \\
\hline $1412-7.32$ & Wildtype & This study \\
\hline \multicolumn{3}{|l|}{ Lactobacillus mucosae } \\
\hline $0713-2$ & Wildtype & [53] \\
\hline $0315-2 B$ & Wildtype & This study \\
\hline \multicolumn{3}{|l|}{ Lactobacillus plantarum } \\
\hline 11017.25 & Wildtype & {$[52]$} \\
\hline $1410-5.32$ & Wildtype & This study \\
\hline \multicolumn{3}{|l|}{ Lactobacillus rossiae } \\
\hline $1410-5.34$ & Wildtype & This study \\
\hline \multicolumn{3}{|l|}{ Pediococcus acidilactici } \\
\hline B-14958 & Wildtype & NRRL \\
\hline \multicolumn{3}{|l|}{ Pediococcus pentosaceus } \\
\hline B-14620 & Wildtype & NRRL \\
\hline
\end{tabular}


Table 1 (continued)

\begin{tabular}{|c|c|c|}
\hline Bacteria and yeast & Relevant genotype/phenotype ${ }^{a, b}$ & Reference or source \\
\hline \multicolumn{3}{|c|}{ Staphylococcus lugdunensis } \\
\hline $1502-8.20$ & Wildtype & \\
\hline \multicolumn{3}{|c|}{ Streptococcus agalactiae } \\
\hline B-1815 & Wildtype & NRRL \\
\hline \multicolumn{3}{|l|}{ Streptococcus uberis } \\
\hline & & USDA \\
\hline \multicolumn{3}{|l|}{ Weissella confusa } \\
\hline $0216-2$ & Wildtype & This study \\
\hline \multicolumn{3}{|c|}{ Saccharomyces cerevisiae } \\
\hline Y-2034 & & NRRL \\
\hline
\end{tabular}

a $\mathrm{Amp}^{\mathrm{R}}$, Ampicillin resistant; $\mathrm{Kan}^{\mathrm{R}}$, kanamycin resistant

b Wildtype microbial strains were isolated from a Midwestern dry-grind fuel ethanol plant and selected from a previous screen [15]

c USDA-ARS Culture Collection, Peoria, IL (also known as the NRRL Collection)

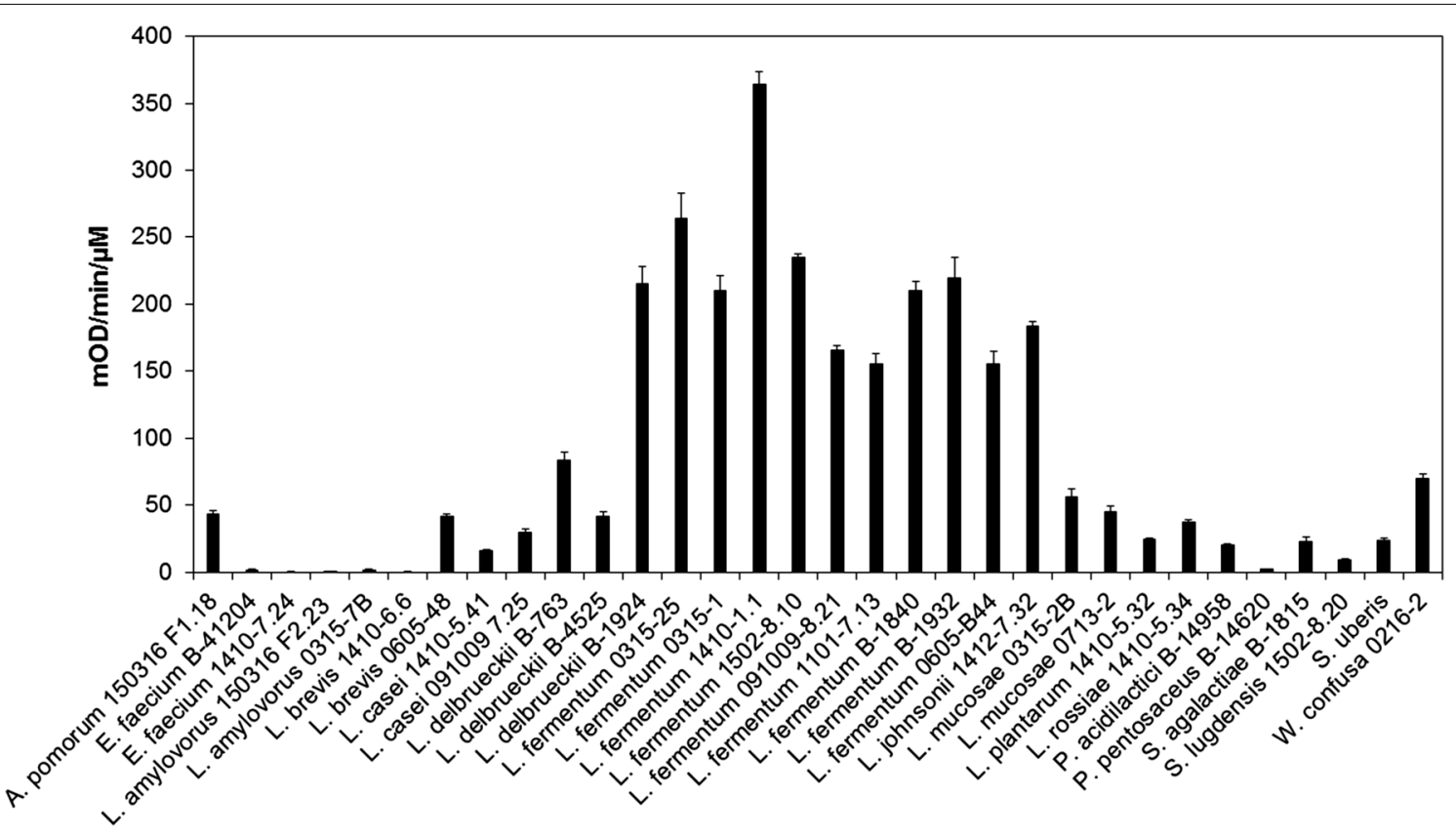

Fig. 4 Activity of LysKB317 endolysin against various strains of bacteria isolated from fuel ethanol fermentation plant. Recombinant LysKB317 was tested for activity against the indicated strains isolated from ethanol fermentation facility using a turbidity reduction assay. In the wells of a 96-well microtiter plate, bacteria were suspended in $100 \mu \mathrm{L}$ assay buffer $\left(300 \mathrm{mM} \mathrm{NaCl}, 30 \%(\mathrm{v} / \mathrm{v})\right.$ glycerol, $21 \mathrm{mM}$ citric acid, 58 mM Na2 $\mathrm{HPO}_{4}, \mathrm{pH}^{2} .5 ; \mathrm{OD}_{600}$ $\mathrm{nm}=2.0)$, and $100 \mu \mathrm{L}$ of enzyme reaction $(1 \mu \mathrm{M})$ added. The change in optical density at $600 \mathrm{~nm}$ was measured over a period of $30 \mathrm{~min}$. Data are reported as the mean change in O.D. per minute per $\mu \mathrm{M}$ enzyme $(n=3$ independent replicates; error bars indicate standard errors of the mean $(\mathrm{SEM}))$

\section{Discussion}

Bacterial contamination is inevitable during the propagation and fermentation processing of fuel ethanol production [12]. Mitigating bacterial contamination using antibiotics and adjustment of fermentation process, such as $\mathrm{pH}$ or temperature, have been used to control infection [23]. In addition, commercially available chemical-based products, such as hop acids and chlorine dioxide, have shown some success [27, 28]. However, there still is a need to improve the current technology by finding alternatives to control bacterial contamination in these types of biorefining processes. In the United States, ethanol production accounts for one of the largest industrial uses of 


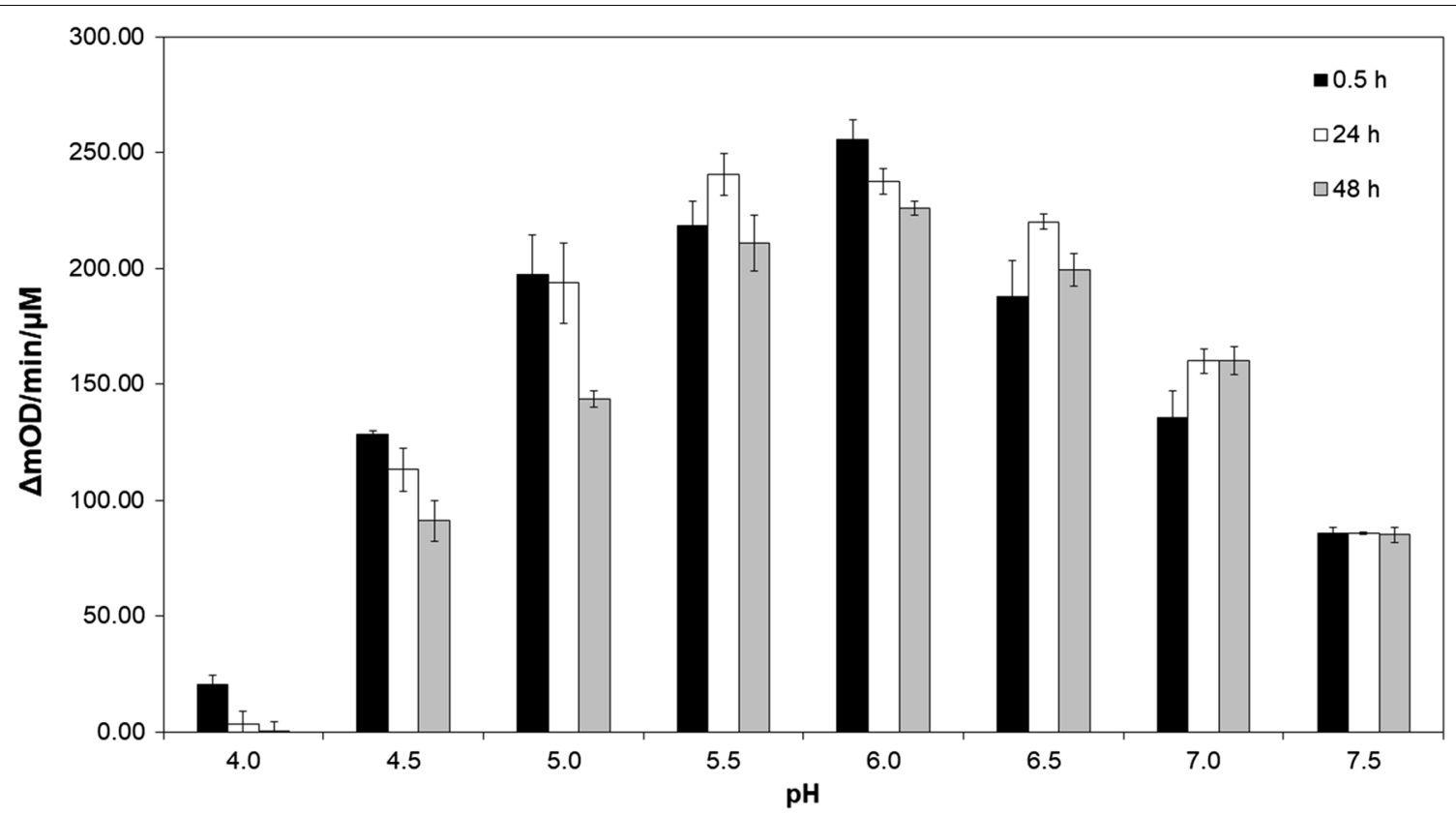

Fig. 5 The endolysin LysKB317 pH stability profile over time under room temperature. Using the turbidity reduction assay, LysKB317 was tested in different $\mathrm{pH}(4.0-7.5)$ assay buffer and shown to be active at $\mathrm{pH}$ as low as 4.5 for $30 \mathrm{~min}$. to pH 7.5 for $48 \mathrm{~h}$. Time frames of $0.5 \mathrm{~h}$ (black bar), $24 \mathrm{~h}$ (white bar), and $48 \mathrm{~h}$ (gray bar) were arbitrary chosen to measure $\mathrm{pH}$ exposure over time. The change in optical density at $600 \mathrm{~nm}$ was measured over a period of $30 \mathrm{~min}$ at $37^{\circ} \mathrm{C}$. Data are reported as the mean change in O.D. per minute per $\mu \mathrm{M}$ enzyme $(n=3$ independent replicates; error bars indicate standard errors of the mean (SEM))

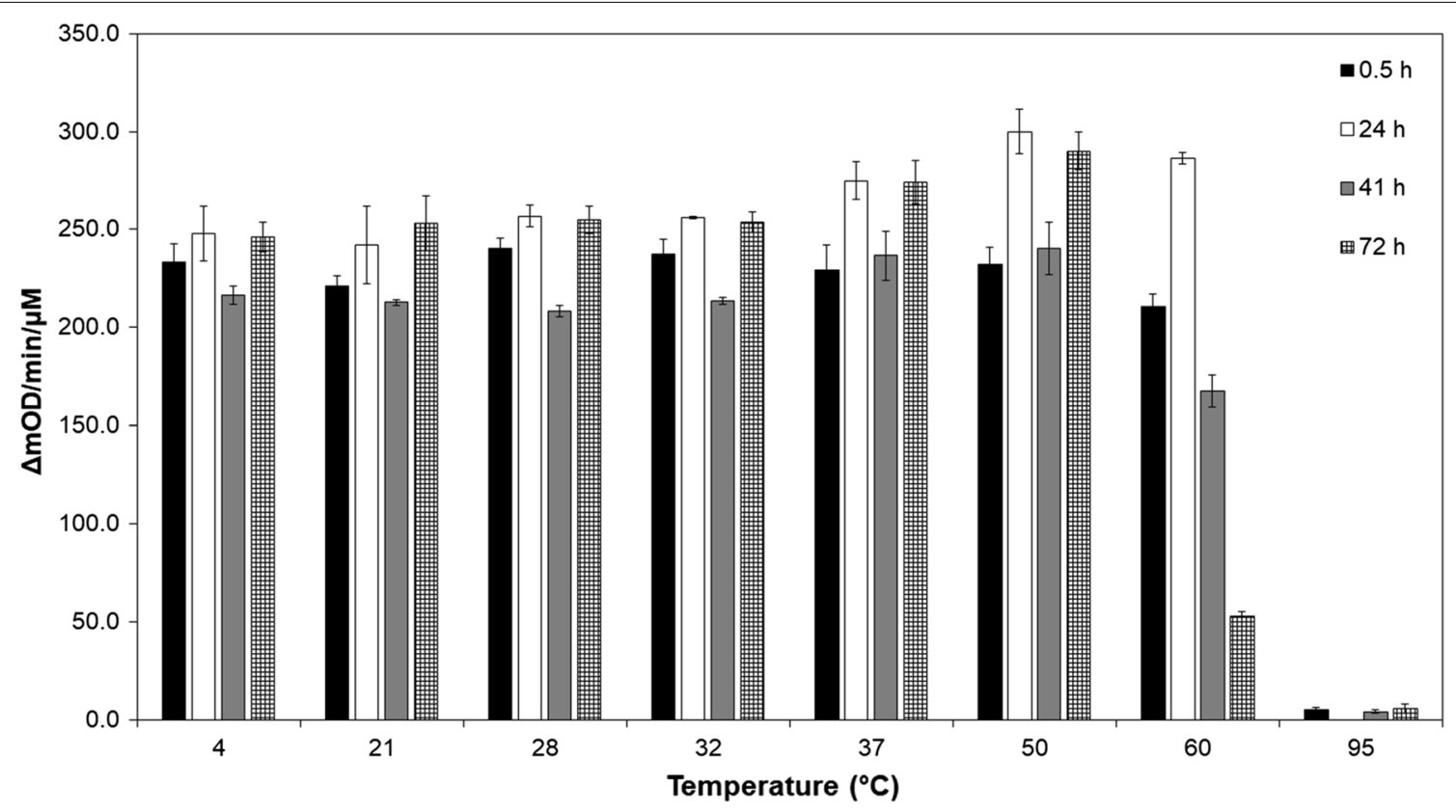

Fig. 6 The endolysin LysKB317 can withstand high temperature of $60^{\circ} \mathrm{C}$ up to $72 \mathrm{~h}$. The temperature stability of the endolysin over time was measured using turbidity reduction assay. A temperature gradient ranging from 4 to $95^{\circ} \mathrm{C}$ was tested over a period of $0.5 \mathrm{~h}$ (black bar), $24 \mathrm{~h}$ (white bar), $41 \mathrm{~h}$ (gray bar), and $72 \mathrm{~h}$ (checker bar). The change in optical density at $600 \mathrm{~nm}$ was measured over a period of 30 min. Data are reported as the mean change in O.D. per minute per $\mu \mathrm{M}$ enzyme ( $n=3$ independent replicates; error bars indicate standard errors of the mean (SEM)) 


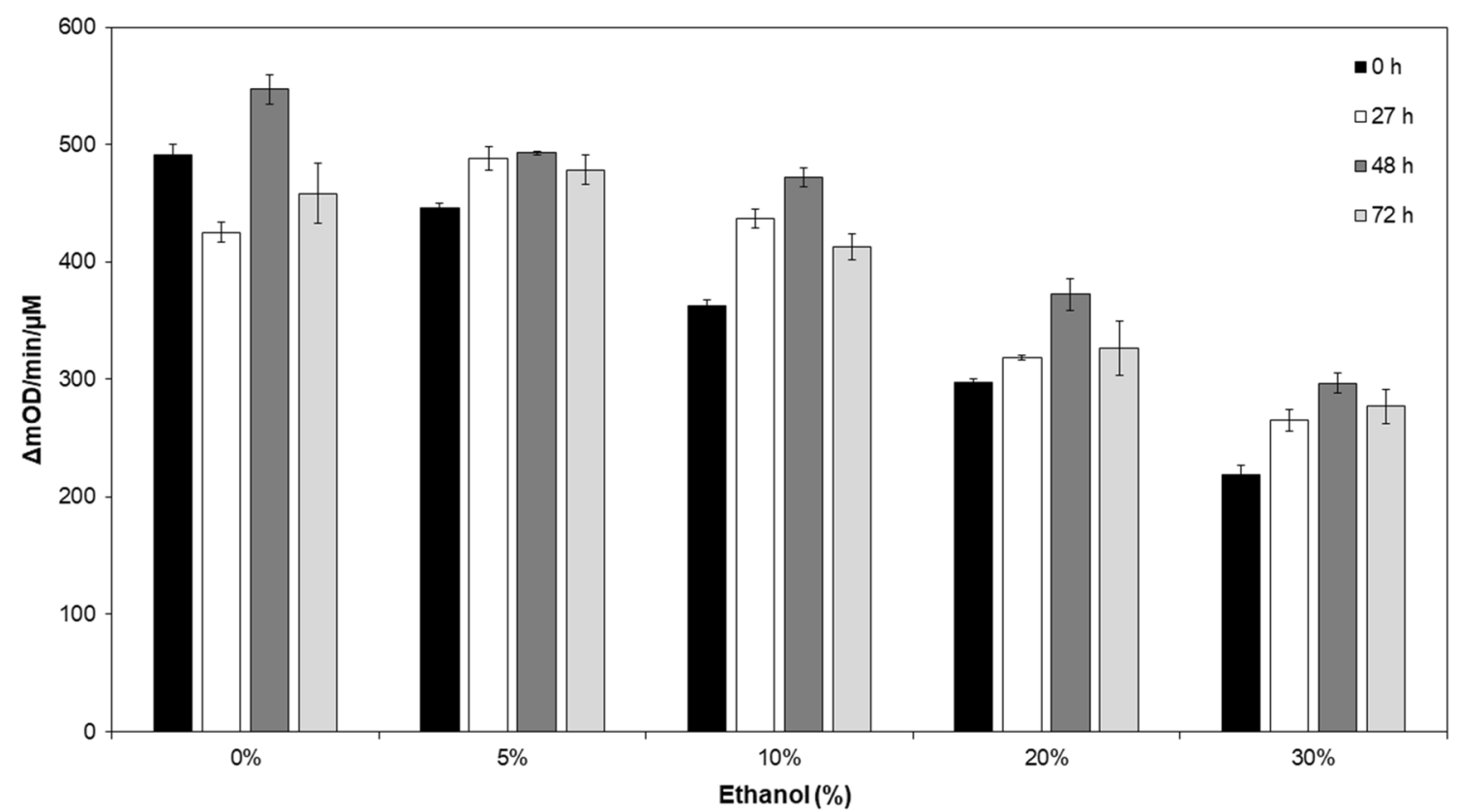

Fig. 7 The endolysin LysKB317 is stable under 30\% ethanol over $72 \mathrm{~h}$ at room temperature. A turbidity reduction assay was performed under various concentration of ethanol $(0 \%, 5 \%, 10 \%, 20 \%$ and $30 \%)$ imitating conditions of LysKB317 would be exposed to in a fermentation tank at a bioethanol refinery plant. A time period of $0 \mathrm{~h}$ (black bar), $27 \mathrm{~h}$ (white bar), $48 \mathrm{~h}$ (dark gray bar), and $72 \mathrm{~h}$ (light gray bar) was used to test the stability of LysKB317 under ethanol exposure. The change in optical density at $600 \mathrm{~nm}$ was measured over a period of $30 \mathrm{~min}$. Data are reported as the mean change in O.D. per minute per $\mu \mathrm{M}$ enzyme ( $n=3$ independent replicates; error bars indicate standard errors of the mean (SEM))

antibiotics consumption [23, 29]. Prolonged excessive usage of antibiotics to treat bacterial contamination has raised concerns on the contribution to antimicrobial resistance $[19,21,23]$. Furthermore, it has been demonstrated that low concentration of biologically active antibiotic such as virginiamycin can persist in distilled grain coproducts when used in ethanol production facilities [30]. Low concentrations of bioactive antibiotics could potentially present a selection pressure resulting in anthropogenic influences that may contribute to bacterial resistance [31-33]. To date, rare accounts of resistance to bacterial peptidoglycan lytic enzymes have been reported, which makes it an effective and desirable alternative treatment to antibiotics [3, 34].

Our goal in this study was to demonstrate that purified endolysin LysKB317 could be a useful tool to mitigate bacterial contamination for the bioethanol industry $[9,14,21]$. The putative endolysin gene LysKB317 was first identified from EcoSau bacteriophage isolated from commercial sauerkraut [24]. The application of purified endolysin LysKB317 has demonstrated a high lytic activity against numerous Gram-positive LAB including several Lactobacillus species such as L. fermentum, which have previously been shown to negatively impact the rate of fermentation and often lead to stuck fermentations $[19,24,35]$.
Purified LysKB317 demonstrated lytic activity against most Lactobacillus species

Based on Pfam protein domain prediction, LysKB317 has a predicted peptidoglycan hydrolase similar to a glycoside hydrolase family 25 LysA-like domain active site (a muramidase) and a bacterial SH3b-like cell wall binding domain (Fig. 1a; [36]). A panel of 32 commonly found bacterial contaminant strains at ethanol fermentation facilities were tested (Table 1), and 26 (81\% effective rate) strains were lysed by LysKB317. As a muramidase, LysKB317 is thought to cleave Gram-positive bacterial cell wall that shared similar peptidoglycan backbone. As a potential method to treat ethanol fermentation contaminants (e.g., L. fermentum), differences in the makeup of peptidoglycan chemotypes could have minimal impact on the catalytic activity of the endolysine to treat infection. Interestingly, in turbidity reduction assay, the highest ( $L$. fermentum) and the lowest (L. amylovorus) lytic activities were all from Lactobacillus species (Fig. 4). Not all peptidoglycan chemotypes of Lactobacillus spp. were equally sensitive to LysKB317 (Table 3; [37-41]) as seen with $L$. fermentum and $L$. mucosae. Differences in affinity of the SH3b cell wall binding domain and/ or accessibility of the LysKB317 could affect target based on differences in strain specific cell wall surface 


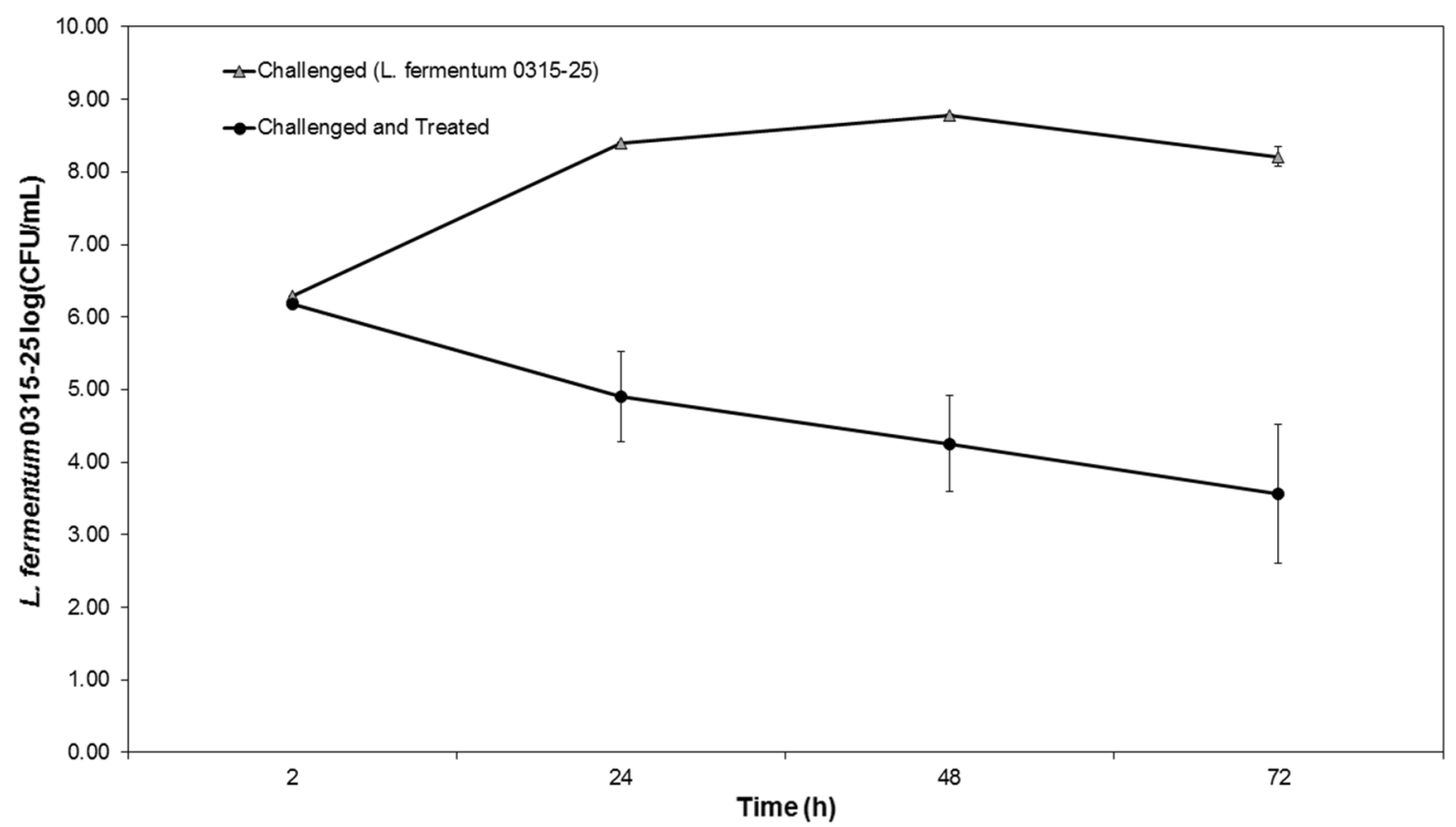

Fig. 8 Small-scaled corn mash fermentation treatment with exogenously added LysKB317 reduced L. fermentum population. Cultures of S. cerevisiae grown on corn mash feedstock alone and exogenously added LysKB317 without L. fermentum challenge (served as negative controls not shown (below detection limit 3-log CFU/mL). Fermented corn mash challenged with $10^{6} \mathrm{CFU} / \mathrm{mL}$ of L. fermentum 0315-25 (gray triangle) served as positive control for contamination. Treatment applied to challenged fermentation corn mash (Black circle) showed significant bacterial contamination reduction over $72 \mathrm{~h}$ closely matching level of unchallenged fermented corn mash at $72 \mathrm{~h}$. Data are reported in $\log \mathrm{CFU} / \mathrm{mL}$ growth of L. fermentum. Bacterial CFU counts were enumerated and log transformed every $24 \mathrm{~h}$ for $72 \mathrm{~h}$ using MRS agar plants. Error bars indicate standard errors of the mean (SEM); three independent replicates. ${ }^{*} P<0.05$ based on one-way ANOVA

Table 2 Treatment model for bacterial load and fermentation products of experimentally infected ethanol fermentations treated with exogenously added LysKB317 endolysin

\begin{tabular}{|c|c|c|c|c|c|}
\hline Treatment & L. fermentum 0315-25 & & & & \\
\hline LysKB317 (nM) & $\log (C F U / m L)$ & Ethanol (g/L) & Glucose (g/L) & Lactic (g/L) & Acetic (g/L) \\
\hline Control & $<3.0$ & $117.4 \pm 7.9$ & $4.5 \pm 2.6$ & $15.2 \pm 0.4$ & $0.9 \pm 0.2$ \\
\hline 0 & $8.4 \pm 0.2$ & $97.0 \pm 7.5$ & $38.9 \pm 2.7$ & $19.8 \pm 0.5$ & $3.6 \pm 0.5$ \\
\hline 1 & $8.6 \pm 0.1$ & $94.6 \pm 1.6$ & $37.2 \pm 0.6$ & $19.9 \pm 0.6$ & $4.3 \pm 0.8$ \\
\hline 10 & $8.5 \pm 0.1$ & $95.8 \pm 7.4$ & $26.1 \pm 4.8$ & $19.7 \pm 0.1$ & $2.7 \pm 0.1$ \\
\hline 100 & $6.5 \pm 0.2$ & $113.1 \pm 3.9$ & $6.9 \pm 4.1$ & $16.3 \pm 0.7$ & $1.4 \pm 0.3$ \\
\hline 1,000 & $6.4 \pm 0.1$ & $115.1 \pm 13$ & $2.1 \pm 0.1$ & $16.6 \pm 0.1$ & $1.3 \pm 0.2$ \\
\hline 10,000 & $4.1 \pm 1.4$ & $118.3 \pm 4.5$ & $0.7 \pm 0.3$ & $15.4 \pm 0.1$ & $1.0 \pm 0.3$ \\
\hline
\end{tabular}

Cultures of S. cerevisiae grown on corn mash feedstock were challenged with $10^{6} \mathrm{CFU} / \mathrm{mL}$ of L. fermentum $0315-25$ [27], and treated with the indicated concentration of recombinant LysKB317 endolysin. The control culture was not challenged with L. fermentum 0315-25. After $72 \mathrm{~h}$ incubation, viable $L$. fermentum was determined by enumeration on MRS agar plates, and the fermentation broth was analyzed by HPLC for the following fermentation products: ethanol, residual glucose, lactic acid, and acetic acid

moieties [42-45] cause interferences to the predicted cleavage site (Fig. 1b). More research is needed to determine the substrate specificity in L. fermentum by LysKB317 compared to L. amylovorus.
Endolysin LysKB317 exhibited a robust and stable characteristic under physical conditions of fermentation Conditions typically found in fuel ethanol fermentation facility fermentation tank can have a temperature ranging 
Table 3 Bacterial peptidoglycan chemotype in this study

\begin{tabular}{lll}
\hline Bacterial contaminants & $\begin{array}{l}\text { Peptidoglycan } \\
\text { chemotype }{ }^{\mathbf{a}, \mathbf{b}}\end{array}$ & References \\
\hline Acetobacter pomorum & A3a L-Ala-D-meso-Dpm & {$[43]$} \\
Enterococcus faecium & A4a L-Lys-D-Asp & {$[39]$} \\
Lactobacillus amylovorus & A4a L-Lys-D-Asp & {$[28,42]$} \\
Lactobacillus brevis & A4a L-Lys-D-Asp & {$[39]$} \\
Lactobacillus casei & A4a L-Lys-D-Asp & {$[39]$} \\
Lactobacillus delbrueckii & A4a L-Lys-D-Asp & {$[39]$} \\
Lactobacillus fermentum & A4ß L-Orn-D-Asx & {$[39,50]$} \\
Lactobacillus johnsonii & A4a L-Lys-D-Asp & {$[42]$} \\
Lactobacillus mucosae & A4ß L-Orn-D-Asp & {$[42]$} \\
Lactobacillus plantarum & A1y meso-Dpm-direct & {$[39]$} \\
Lactobacillus rossiae & N/A ${ }^{\text {b }}$ & \\
Pediococcus acidilactici & A4a L-Lys-D-Asp & {$[39]$} \\
Pediococcus pentosaceus & A4a L-Lys-D-Asp & {$[42]$} \\
Staphylococcus lugdunensis & N/A ${ }^{\text {b }}$ & \\
Streptococcus agalactiae & N/A ${ }^{\text {b }}$ & \\
Streptococcus uberis & A3a L-Lys-L-Ala 2 & {$[42]$} \\
Weissella confuse & A3a L-Lys-L-Ala & {$[42]$}
\end{tabular}

a Dpm, 2,6-diaminopimelic acid; Orn, L-ornithine [28, 42]

b $\mathrm{N} / \mathrm{A}$, not available

from 30 to $35{ }^{\circ} \mathrm{C}$ (thermotolerant yeast strain $42-45{ }^{\circ} \mathrm{C}$ [46]) and $\mathrm{pH}$ range from $\mathrm{pH} 4$ to 5.5 with an ethanol concentration no higher than $25 \%$ concentration for up to $48 \mathrm{~h}$. The stability of the LysKB317 endolysin under such conditions is considered by us to be an effective alternative to antibiotics ([47]; Figs. 5, 6 and 7).

\section{LysKB317 is effective under small-scale corn mash fermentation conditions}

Exogenous addition of purified LysKB317 alone was sufficient and successful in treating and controlling infected corn mash matrix (Fig. 8). Effective treatment seen in $50 \mathrm{~mL}$ Erlenmeyer flasks (Table 2) was encouraging in control L. fermentum bacterial load. The effectiveness in controlling bacterial contamination is also reflected upon the level of acetic and lactic acid in reducing the byproducts and restored ethanol production. Alternative methods to increase production of the lysin could be beneficial and will reduce cost at the industrial scale. Nevertheless, current method of exogenous addition of purified LysKB317 alone was able to control L. fermentum contamination and restore healthy fermentation characteristics.

\section{Conclusion}

Bacteriophage-derived lytic endolysin enzyme such as LysKB317 is a strong candidate of antimicrobial control against LAB contamination in fuel ethanol fermentations.
LysKB317 demonstrated the ability to lyse L. fermentum at $\mathrm{pH}$, temperature, and ethanol concentrations similar to conditions found during fuel ethanol fermentations by at least two-log fold change in small-scale corn-mash fermentation. These qualities make LysKB317 an excellent candidate for antimicrobial control for use in biofuel fermentations.

\section{Methods \\ Bacterial and yeast strains and culture conditions}

Wildtype bacterial strains were isolated from a Midwestern dry-grind fuel ethanol plant and selected from a previous screen [15]. Unless otherwise stated, all bacterial strains described here (Table 1) were grown in its respective culture media. Escherichia coli strains in Miller's LB (LB broth) medium (Difco Laboratories, Inc.). When used, ampicillin (Amp; Sigma-Aldrich, Inc.) at $100 \mu \mathrm{g} /$ $\mathrm{mL}$ or kanamycin (Kan; Sigma-Aldrich, Inc.) at $50 \mu \mathrm{g} / \mathrm{mL}$ was added to LB media when required. Here we acknowledge newly reclassification and genera naming of some Lactobacillus spp. listed in this study (e.g., Lactobacillus fermentum as Limosilactobacillus fermentum and Lactobacillus mucosae as Limosilactobacillus mucosae) [48]. For consistency, older species names are being used here. Lactobacillus spp. and Weissella. were grown in Lactobacilli MRS (MRS broth) medium (Difco Laboratories, Inc.). Acetobacter and Pediococcus were grown in rapid lemonade spoilage organism broth (RLS broth; Sigma-Aldrich). Enterococcus strains were cultured in brain heart infusion broth (BHI; Bacto). Streptococcus were grown in tryptic soy broth (TSB; Difco Laboratories, Inc.). Unless otherwise stated, bacterial strains were inoculated at $37{ }^{\circ} \mathrm{C}$ with shaking (200 rpm), with expectation to Lactobacillus spp. (standstill incubation). Saccharomyces cerevisiae was grown in yeast extract peptone broth (YPD; BD Biosciences) at $32{ }^{\circ} \mathrm{C}$ with shaking (200 rpm).

\section{Construct, strains, and plasmids}

Bacteriophage EcoSau endolysin gene (LysKB317; GenBank accession number KP027015.1; protein accession number AIY32273.1 [24]) was codon optimized for $E$. coli expression and synthesized by GenScript (Table 4). Plasmid pUC57 carrying LysKB317 was transformed into E. coli (E. cloni 10G; Lucigen Co.) for plasmid propagation (Table 1). Primer set Sau_F and Sau_R (Table 5) was used to amplify the 894 bp LysKB317 gene insert. PCR amplicon was cleaned using QIAquick PCR purification kit (Qiagen) and cloned into pRham N-His Kan vector (Table 4) using E. coli strain E. cloni 10G (Lucigen Co., Table 1) per manufacture protocol. The LysKB317 plasmid construct was Sanger sequenced verified using primer set pRham_F and pETite_R (Table 5). 
Table 4 Plasmids used in this study

\begin{tabular}{ll}
\hline Plasmid & Relevant genotype $^{\mathbf{a}}$ \\
\hline pUC57::LysKB317 & Amp $^{R}$, containing LysKB317 gene fragment \\
pRham N-His Kan & Kan $^{R}$, Expresso rhamnose cloning vector \\
pRham N-His Kan::LysKB317 & Kan $^{R}$, containing the LysKB317 \\
\hline
\end{tabular}

Table 5 Primers used in this study

\begin{tabular}{llc}
\hline Primer name & Sequence $\left(\mathbf{5}^{\prime} \mathbf{- 3} \mathbf{3}\right)$ & Purpose \\
\hline Sau_F & CATCATCACCACCATCACGCACTTTACGTAGTTGACGTT & Amplification of LysKB317 for \\
Sau_R & GTGGCGGCCGCTCTATTATTTAAAGGTTCCGAATGCTTC & This study \\
PRham_F & GCTTTTTAGACTGGTCGTAGGGAG & Verify gene insert \\
PETite_R & CTCAAGACCCGTTTAGAGGC & \\
\hline
\end{tabular}

\section{Expression and purification of LysKB317}

Commercially available Gram-negative E. coli Expresso SUMO protein expression system (Lucigen) was used to express Gram-positive Lactobacilli toxin. The LysKB317 endolysin protein was over expressed in E. coli (E. cloni 10G/pRham N-His Kan::LysKB317; Table 1) via 0.2\% $(\mathrm{w} / \mathrm{v})$ L-rhamnose (Sigma) induction in $1 \mathrm{~L}$ LB broth with Kan at $37{ }^{\circ} \mathrm{C}$ shaking $(200 \mathrm{rpm})$ overnight. Cells were harvested by $4{ }^{\circ} \mathrm{C}$ centrifugation at $5,000 \times g$ for $20 \mathrm{~min}$. Cells were then lysed with B-PER (Thermo Scientific) and the addition of freshly prepared lysozyme $(20 \mathrm{mg} /$ $\mathrm{mL}$ in $1 \mathrm{mM}$ Tris-HCl, pH8.0; Thermo Scientific), DNaseI (10 U/mL; Thermo Scientific), and RNase I (10 U/ $\mathrm{mL}$; Thermo Scientific), followed by gentle inversion for $20 \mathrm{~min}$ at room temperature. Soluble protein fraction was separated from whole cell lysate via $15,000 \times g$ centrifugation at $4{ }^{\circ} \mathrm{C}$ for $5 \mathrm{~min}$ and purified using HisPur Ni-NTA Superflow Agarose (Thermo Scientific). Nickel resin was washed with 40 column volumes $(\mathrm{CV})$ of lysis buffer, and $15 \mathrm{CV}$ of wash buffer $\left(50 \mathrm{mM} \mathrm{NaH} \mathrm{PO}_{4}\right.$, $300 \mathrm{mM} \mathrm{NaCl}, 20 \mathrm{mM}$ imidazole, and 30\% glycerol, $\mathrm{pH}$ 8.0). Bound LysKB317 $\mathrm{His}_{6}$-tagged protein was eluted with elution buffer $\left(50 \mathrm{mM} \mathrm{NaH} \mathrm{PO}_{4}, 300 \mathrm{mM} \mathrm{NaCl}\right.$, $250 \mathrm{mM}$ imidazole, and 30\% glycerol, $\mathrm{pH}$ 8.0) and filter sterilized with $0.22 \mu \mathrm{m}$. Concentration of protein was determined using a Qubit 3 fluorometer (Thermo Fisher Scientific) and Qubit Protein Assay Kit (Thermo Fisher Scientific). A sodium dodecyl sulfate (SDS)-polyacrylamide gel electrophoresis (PAGE) was used to determine the protein purities. Purified N-terminus His-tagged LysKB317 recombinant protein was resuspended in $1 \times$ Laemmli sample buffer (Bio-Rad laboratories, Inc.) and boiled for 5-10 min. Fifteen microliters of the boiled sample and protein standard (Precision Plus Protein All Blue standard; Bio-Rad) were loaded side-by-side onto an Any kD Tris-glycine precast gel (Bio-Rad) for (SDSPAGE) protein separation at $100 \mathrm{~V}$ for $70 \mathrm{~min}$. The gel was stained with LabSafe Gel Blue stain (G-Biosciences) for $1 \mathrm{~h}$ at room temperature with gentle agitation, and then destained with deionized (DI) water for at least $1 \mathrm{~h}$.

\section{Expression and purification of endolysin LysA}

The endolysin LysA (36.4 kD; glycosidase) known to inhibit Lactobacilli spp. was chosen as an endolysin comparison to LysKB317 [4]. E. coli BL21(DE3)/ pET21a::LysA (Table 1) was induced similar to previously discussed methods [49] with $0.5 \mathrm{mM}$ of isopropyl $\beta$-D1-thiogalactopyranoside (IPTG; Sigma) in LB broth and ampicillin $(100 \mu \mathrm{g} / \mathrm{mL})$ overnight at $37^{\circ} \mathrm{C}$ with agitation. LysA endolysin was purified using methods described above.

\section{Western blot analysis}

Purified $N$-terminus His-tagged LysKB317 recombinant protein described above was separated by SDS-PAGE as previously described. A Trans-Blot turbo transfer system (Bio-Rad) was used for protein transfer onto a low-fluorescence polyvinylidene difluoride (PVDF) membrane with $0.2 \mu \mathrm{m}$ pore size (Bio-Rad). Protein electrophoresis transfer was verified using Ponceau S staining (Cell Signaling Technology, Inc.). Nonspecific binding was blocked by $3 \%$ bovine serum albumin (BSA) in $1 \times$ tris-buffered saline (TBS) containing 0.1\% Tween-20 (Sigma-Aldrich). Mouse anti-His-tag antibody conjugated to DyLight 488 was applied and incubated at $4{ }^{\circ} \mathrm{C}$ overnight $(1: 1,000$; Thermo Fisher Scientific). Fluorescent band signals were detected using a ChemiDoc XRS + imaging system (Bio-Rad). 


\section{Spot plate assay}

Bacterial strains (Table 1) were inoculated in $5 \mathrm{~mL}$ MRS at $37{ }^{\circ} \mathrm{C}$ without shaking and grown to $\mathrm{OD}_{600 \mathrm{~nm}}$ of approximately 0.8 . Bacterial strains $(1 \mathrm{~mL})$ were then mixed with $0.7 \%$ agar $\left(50{ }^{\circ} \mathrm{C}\right)$, and $0.5 \mathrm{~mL}$ of plate buffer (50 $\mathrm{mM} \mathrm{NaH}_{2} \mathrm{PO}_{4}, \mathrm{pH} 7.0$ ), then poured onto pre-solidified regular MRS agar plate (1.6\%) and allowed to air dry. Purified LysKB317 protein at a pre-determined concentration $[1.0 \mu \mathrm{M} ; 5 \mu \mathrm{L}]$ was pipetted onto the MRS agar and dried for $10-15 \mathrm{~min}$. Sterile water was used as negative control. The plate was then incubated at $37{ }^{\circ} \mathrm{C}$ overnight. Strains that exhibited zones of clearance were deemed susceptible to LysKB317. As controls, $5 \mu \mathrm{L}$ of MRS broth served as the negative control and $5 \mu \mathrm{L}$ of $20 \mu \mathrm{g} / \mathrm{mL}$ purified endolysin LysA and lysozyme separately served as the positive control [50].

\section{Zymogram}

Zymogram analysis was performed based on a previously described method with slight modification [4]. Briefly, $L$. fermentum 0315-25 cells (Table 1) were grown to mid-log phase in $50 \mathrm{~mL}$ MRS media and pelleted at $4,000 \times \mathrm{g}$ for $15 \mathrm{~min}$. Cells were washed with $10 \mathrm{~mL}$ of zymogram buffer (10 mM Tris, $150 \mathrm{mM} \mathrm{NaCl}, \mathrm{pH}$ 7.5), harvested and resuspended in $300 \mu \mathrm{L}$ zymogram buffer resulting in a final volume of approximately $600 \mu \mathrm{L}$. The purified LysKB317 protein described above, and protein standard (Precision Plus Protein All Blue standard; Bio-Rad) were run in parallel in two separate 15\% SDS-PAGE gels. One gel contained $600 \mu \mathrm{L}$ of resuspended L. fermentum 0315-25 cell (zymogram), and the other gel contained only $600 \mu \mathrm{L}$ of buffer (negative control). Each of which was added prior to gel polymerization. Gels were electrophoresed for 1-2 $\mathrm{h}$ at $150 \mathrm{~V}$ until completion. SDS-PAGE gels were stained using LabSafe GEL Blue (G-Biosciences) and washed in deionized (DI) water for $1 \mathrm{~h}$ at room temperature. Additional de-staining incubation was done with gels submerged in de-staining buffer (50 mM Tris- $\mathrm{HCl}, 1 \%$ Triton X-114, $\mathrm{pH}$ 5.5 ) at room temperature with gentle swirling overnight or until translucent bands is clearly visible as described [49].

\section{Turbidity reduction assay}

Turbidity reduction assay was performed at $37{ }^{\circ} \mathrm{C}$, unless otherwise stated, in Synergy 2 Microplate Reader (BioTek Inc.) with purified LysKB317 protein (described above) diluted in turbidity reduction assay buffer $(300 \mathrm{mM} \mathrm{NaCl}$, $30 \%$ (v/v) glycerol, $21 \mathrm{mM}$ citric acid, $58 \mathrm{mM} \mathrm{NaH}_{2} \mathrm{PO}_{4}, \mathrm{pH}$ 5.5) to $1 \mu \mathrm{M}$ concentration. Lactobacillus cultures (listed in Table 1) used in the turbidity reduction assay were prepared as previously described [4]. Briefly, bacterial cells were inoculated in $50 \mathrm{~mL}$ MRS media and grown to mid-log phase. Cells were washed in phosphate-buffered saline (PBS; pH $7.4,30 \%$ glycerol) before being adjusted to an optical density
$\left(\mathrm{OD}_{600 \mathrm{~nm}}\right)=2.0$. Aliquots of $1 \mathrm{~mL}$ of cells were then centrifuged and pellet resuspended in $1 \mathrm{~mL}$ of turbidity reduction assay buffer. Each of the designated experimental wells of a 96-well microtiter plate (flat bottom; Falcon) contained $100 \mu \mathrm{L}$ bacterial suspension and $100 \mu \mathrm{L}$ of $1 \mu \mathrm{M}$ endolysin. Wells containing bacterial cell suspension $(100 \mu \mathrm{L})$ without endolysin $(100 \mu \mathrm{L}$ turbidity reduction assay buffer) were used to control the rate of autolysis of bacterial cells. Immediately upon addition of endolysin to bacterial suspension, absorbance readings $\left(\mathrm{OD}_{600}\right)$ were recorded every $30 \mathrm{~s}$ for $30 \mathrm{~min}$. Treatment and control wells were run in triplicates. Specific actives were determined by $\left(\Delta \mathrm{mOD}_{600 \mathrm{~nm}} / \mathrm{min} / \mu \mathrm{M}\right)$ described by Becker et al. [51].

\section{Temperature, $\mathrm{pH}$ and ethanol sensitivity assays}

Thermostability of LysKB317 was determined by placing $1 \mu \mathrm{M}$ of purified endolysin in turbidity reduction assay buffer at each pre-determined temperature $\left(4^{\circ}, 21^{\circ}, 28^{\circ}\right.$, $32^{\circ}, 37^{\circ}, 50^{\circ}, 60^{\circ}$, and $95^{\circ} \mathrm{C}$ ) and incubated for $0.5,24,41$, and $72 \mathrm{~h}$ before performing the turbidity reduction assay described above at $37{ }^{\circ} \mathrm{C}$. In a similar fashion, $1 \mu \mathrm{M}$ of purified LysKB317 was added to pre-determined turbidity reduction assay buffer at $\mathrm{pH} 4.0,4.5,5.0,5.5,6.0,6.5$, 7.0, and 7.5 (21 mM citric acid, $58 \mathrm{mM} \mathrm{NaH}_{2} \mathrm{PO}_{4}$ buffer adjusted to the $\mathrm{pH}$ indicated) for $0.5,24$, and $48 \mathrm{~h}$ at room temperature prior to performing the turbidity reduction assay as described above for $30 \mathrm{~min}$ at $37^{\circ} \mathrm{C}$. Ethanol from $0-30 \%(\mathrm{~g} / 100 \mathrm{ml})$ concentrations was added to the LysKB317 buffer for pre-determined amount of time $(0-72 \mathrm{~h})$ before performing the turbidity reduction assay.

\section{Preparation of small-scale corn mash fermentation}

This was done as described in Bischoff et al. and Roach et al. $[4,35]$. Briefly, the S. cerevisiae strain NRRL Y-2034 (Table 1) was grown overnight in YP broth supplemented with $5 \%(\mathrm{w} / \mathrm{v})$ glucose at $32{ }^{\circ} \mathrm{C}$ with $200 \mathrm{rpm}$ shaking. The infection L. fermentum strain 0315-25 (Table 1) was grown in static MRS media at $37{ }^{\circ} \mathrm{C}$ to mid-log phase $\left(\mathrm{OD}_{600} \mathrm{~nm}=0.4-0.6\right)$. Both yeast and bacteria cells were collected via centrifugation and inocula were resuspended in sterile phosphate-buffered saline (PBS; pH 7.4, Fisher Scientific) to $\mathrm{OD}_{600} \mathrm{~nm}$ equivalent of 80 for yeast, and $\mathrm{OD}_{600} \mathrm{~nm}$ equivalent of 8.0 for L. fermentum $0315-25$. One $\mathrm{OD}_{600} \mathrm{~nm}$ is approximately $6 \times 10^{7} \mathrm{CFU} /$ $\mathrm{mL}$ for yeast and $1 \times 10^{8} \mathrm{CFU} / \mathrm{mL}$ for bacteria. Corn mash (approximately 33\% solids) was collected from a commercial dry-grind ethanol facility and stored at $-20{ }^{\circ} \mathrm{C}$. Verification of aliquots of corn mash samples onto MRS agar did not detect transient bacteria in the mash $\left(<10^{2} \mathrm{CFU} / \mathrm{mL}\right)$. In separate $50 \mathrm{~mL}$ Erlenmeyer flasks, $40 \mathrm{~mL}$ corn mash with ammonium sulfate $(0.12 \%$, w/v) and glucoamylase ( $20 \mu \mathrm{L}$ of Optidex L-500; Genecor International Inc.) were dispensed. 
Purified endolysin LysKB317 $(1 \mu \mathrm{M})$ was added with $0.5 \mathrm{~mL}$ S. cerevisiae inoculum and when indicated, $0.5 \mathrm{~mL}$ challenged bacterial inoculum was added sequentially at time 0 . Each flask was plugged with a rubber stopper containing a 20-gauge $0.9 \mathrm{~mm} \times 40 \mathrm{~mm}$ PrecisionGlide needle (Becton Dickinson) to vent excess $\mathrm{CO}_{2}$. Flasks were initially incubated at $32{ }^{\circ} \mathrm{C}$ with $100 \mathrm{rpm}$ shaking for $3 \mathrm{~h}$ to acclimate yeast. All fermentation flasks were briefly removed from the incubator prior to the beginning of the experiment. Designated flasks were then seeded with $0.5 \mathrm{~mL}$ of $L$. fermentum with half of the flasks getting endolysin treatment before all flasks were returned to the incubator $\left(32^{\circ} \mathrm{C}\right.$ and $100 \mathrm{rpm}$ shaking). Two-hundred fifty microliters of samples were taken at $0,0.5,1.0,1.5,4,48$, and $72 \mathrm{~h}$ and diluted in PBS (pH 7.4, 1:10). Time course up to $72 \mathrm{~h}$ was chosen as most fermentation without bacterial contamination has been shown to be completed by $72 \mathrm{~h}$ [52]. Fermentation samples were tittered for bacterial counts on $1.5 \%$ MRS agar and yeast inhibitor $(100 \mu \mathrm{g} / \mathrm{mL}$; cycloheximide) by serial dilution plating using the Eddy Jet 2 spiral plater (IUL Instruments) set in the E mode 50 (50 $\mu \mathrm{L}$ sample). Plates were then incubated anaerobically using the Anaero Pack System (Mitsubishi) at $37{ }^{\circ} \mathrm{C}$ for $18 \mathrm{~h}$ [49]. Colony forming unit $/ \mathrm{mL}(\mathrm{CFU} / \mathrm{mL})$ were numerated using a Flash \& Go plate reader (IUL Instruments) with $\geq 10$ CFU minimum detection limit at $3.3 \log _{10}$ (CFU/ $\mathrm{mL}$ ). Based on unpublished data, LysKB317 does not show any detectable inhibitory effect against $S$. cerevisiae, thus no yeast cell counts were collected. As previously described, a high-performance liquid chromatography (HPLC) system with $300 \mathrm{~mm}$ Aminex HPX 87H column (Bio-Rad laboratories, Inc.) was used to quantify presence of acetic acid, galactose, glucose, and lactic acid [35].

\section{Statistical analysis}

Where appropriate, experimental results were analyzed using one-way analysis of variance (ANOVA) test (Microsoft Excel 2019).

\section{Supplementary information}

Supplementary information accompanies this paper at https://doi. org/10.1186/s13068-020-01795-9.

Additional file 1. Additional figures.

\section{Abbreviations}

ANOVA: Analysis of variance; BHI: Brain heart infusion broth; BSA: Bovine serum albumin; CFU: Colony forming unit; HPLC: High-performance liquid chromatography; IPTG: Isopropyl-B-D-1-thiogalactopyranoside; LAB: Lactic acid bacteria; LB: Luria-Bertani; MRS: De man, rogosa and sharp; OD: Optical density; PBS: Phosphate-buffered saline; PVDF: Polyvinylidene difluoride membrane; RLS: Rapid lemonade spoilage organism broth; SDS-PAGE: Sodium dodecyl sulfate-polyacrylamide gel electrophoresis; SEM: Standard errors of the mean; TBS: Tris-buffered saline; TSB: Tryptic soy broth; YP: Yeast extract peptone.

\section{Acknowledgments}

The authors thank David Donovan for providing the S. uberis strain (ARS, USDA, Beltsville, MD). The authors would like to thank Amber Anderson and Eric Hoecker for excellent technical assistant. The authors dedicate this study to the memory of their friend and colleague, Dr. Kenneth Bischoff.

The U.S. Department of Agriculture (USDA) prohibits discrimination in all its programs and activities on the basis of race, color, national origin, age, disability, and where applicable, sex, marital status, family status, parental status, religion, sexual orientation, genetic information, political beliefs, reprisal, or because all or part of an individual's income is derived from any public assistance program. The USDA is an equal opportunity provider and employer.

\section{Authors' contributions}

$S Y L, K M B$, and CDS designed and performed experiments involving phage endolysin, purification, and SYL performed characterization of activities by zymogram and turbidity reduction assays and was the lead author of this manuscript. KMB and JOR performed small-scale corn mash fermentation experiments. All authors read and approved the final manuscript.

\section{Funding}

Not applicable. No grant money was used for this research

\section{Availability of data and materials}

Data and material will be available on Ag Data Commons at https://www.data. nal.usda.gov

\section{Ethical approval and consent to participate}

Not required.

\section{Consent for publication}

All authors approved the manuscript for publication

\section{Competing interests}

The authors declare no competing financial interests. Mention of a trade name, proprietary product, or specific equipment does not constitute a guarantee or warranty by the United States Department of Agriculture and does not imply its approval to the exclusion of other products that may be suitable.

\section{Author details}

${ }^{1}$ Renewable Product Technology Research Unit, National Center for Agricultural Utilization Research, Agricultural Research Service, U.S. Department of Agriculture, 1815 North University Street, Peoria, IL 61604-3902, USA.

${ }^{2}$ Agricultural Research Service, U.S. Department of Agriculture, Fort Collins, CO 80526, USA.

Received: 26 June 2020 Accepted: 27 August 2020

Published online: 08 September 2020

\section{References}

1. Schmelcher M, Donovan DM, Loessner MJ. Bacteriophage endolysins as novel antimicrobials. Fut Microbiol. 2012;7(10):1147-71.

2. Fischetti VA. Bacteriophage lysins as effective antibacterials. Curr Opin Microbiol. 2008;11(5):393-400.

3. Loessner MJ. Bacteriophage endolysins - current state of research and applications. Curr Opin Microbiol. 2005;8(4):480-7.

4. Roach DR, Khatibi PA, Bischoff KM, Hughes SR, Donovan DM. Bacteriophage-encoded lytic enzymes control growth of contaminating Lactobacillus found in fuel ethanol fermentations. Biotechnol Biofuels. 2013;6(1):20.

5. Report EUSFEPPC. Fuel Ethanol Overview. In. Edited by Administration USEI, vol. 2019: U.S. Energy Information Administration; 2019: 179.

6. Ugarte DG, English BC, Jensen K. Sixty billion gallons by 2030: Economic and agricultural impacts of ethanol and biodiesel expansion. Am J Agric Econ. 2007;89(5):1290-5.

7. James A. Duffield RJaSM: US ethanol: an examination of policy, production, use, distribution, and market interactions. Agriculture USDo. Washington: USDA; 2015. p. 87.

8. Moschini G, Lapan H, Kim H. "The renewable fuel standard in competitive equilibrium: market and welfare effects"-authors' response to comment. Am J Agric Econ. 2017;99(5):1146-7. 
9. Skinner KA, Leathers TD. Bacterial contaminants of fuel ethanol production. J Ind Microbiol Biotechnol. 2004;31 (9):401-8.

10. Gonçalves C. Bacterial contaminants and their effects on alcohol production. 3rd ed. Nottingham: Nottingham University Press; 1997.

11. Joseph O, Rich AMA, Timothy DL, Bischoff KM, Siqing L, Christopher DS. Microbial contamination of commercial corn-based fuel ethanol fermentations. Bioresour Technol Rep. 2020:11:12.

12. Beckner M, Ivey ML, Phister TG. Microbial contamination of fuel ethanol fermentations. Lett Appl Microbiol. 2011:53(4):387-94.

13. Schell DJ, Dowe N, Ibsen KN, Riley CJ, Ruth MF, Lumpkin RE. Contaminant occurrence, identification and control in a pilot-scale corn fiber to ethanol conversion process. Bioresour Technol. 2007;98(15):2942-8.

14. Muthaiyan A, Limayem A, Ricke SC. Antimicrobial strategies for limiting bacterial contaminants in fuel bioethanol fermentations. Prog Energ Combust. 2011;37(3):351-70.

15. Rich JO, Leathers TD, Bischoff KM, Anderson AM, Nunnally MS. Biofilm formation and ethanol inhibition by bacterial contaminants of biofuel fermentation. Bioresour Technol. 2015;196:347-54.

16. Bischoff KM, Liu SQ, Leathers TD, Worthington RE, Rich JO. Modeling bacterial contamination of fuel ethanol fermentation. Biotechnol Bioeng. 2009;103(1):117-22.

17. Makanjuola DB, Tymon A, Springham DG. Some effects of lactic-acid bacteria on laboratory-scale yeast fermentations. Enzyme Microb Tech. 1992:14(5):350-7.

18. Narendranath NV, Hynes SH, Thomas KC, Ingledew WM. Effects of Lactobacilli on yeast-catalyzed ethanol fermentations. Appl Environ Microbiol. 1997:63(11):4158-63.

19. Bischoff KM, Skinner-Nemec KA, Leathers TD. Antimicrobial susceptibility of Lactobacillus species isolated from commercial ethanol plants. J Ind Microbiol Biot. 2007;34(11):739-44.

20. Narendranath NV, Thomas KC, Ingledew WM. Effects of acetic acid and lactic acid on the growth of Saccharomyces cerevisiae in a minimal medium. J Ind Microbiol Biot. 2001;26(3):171-7.

21. Narendranath NV. Bacterial contamination and control in ethanol production. The alcohol textbook. 4th ed. Thrumpton: Nottingham University Press; 2003. p. 287-298.

22. Meek RW, Vyas H, Piddock LJ. Nonmedical uses of antibiotics: time to restrict their use? PLoS Biol. 2015;13(10):e1002266.

23. Walter AL, Yang D, Zeng Z, Bayrock D, Urriola PE, Shurson GC. Assessment of antibiotic resistance from long-term bacterial exposure to antibiotics commonly used in fuel ethanol production. World J Microbiol Biotechnol. 2019:35(4):66.

24. Liu M, Bischoff KM, Gill JJ, Mire-Criscione MD, Berry JD, Young R, Summer EJ. Bacteriophage application restores ethanol fermentation characteristics disrupted by Lactobacillus fermentum. Biotechnol Biofuels. 2015:8:132.

25. Schleifer KH, Kandler O. Peptidoglycan types of bacterial cell walls and their taxonomic implications. Bacteriol Rev. 1972;36(4):407-77.

26. Simelyte E, Rimpilainen M, Zhang X, Toivanen P. Role of peptidoglycan subtypes in the pathogenesis of bacterial cell wall arthritis. Ann Rheum Dis. 2003;62(10):976-82.

27. Ruckle L, Senn T. Hop acids can efficiently replace antibiotics in ethanol production. Int Sugar J. 2006;108(1287):139-47.

28. Meneghin SP, Reis FC, de Almeida PG, Ceccato-Antonini SR. Chlorine dioxide against bacteria and yeasts from the alcoholic fermentation. Braz J Microbiol. 2008;39(2):337-43.

29. Martin MJ, Thottathil SE, Newman TB. Antibiotics overuse in animal agriculture: a call to action for health care providers. Am J Public Health. 2015;105(12):2409-10.

30. Bischoff KM, Zhang YH, Rich JO. Fate of virginiamycin through the fuel ethanol production process. World J Microb Biot. 2016;32:5.

31. Thiele-Bruhn S. Pharmaceutical antibiotic compounds in soils-a review. J Plant Nutr Soil Sc. 2003;166(2):145-67.

32. Kummerer K. Antibiotics in the aquatic environment-a review_-Part I. Chemosphere. 2009;75(4):417-34.

33. Wistrand-Yuen E, Knopp M, Hjort K, Koskiniemi S. Berg OG. Andersson DI: Evolution of high-level resistance during low-level antibiotic exposure. Nat Commun; 2018. p. 9.

34. Fischetti VA. Bacteriophage endolysins: a novel anti-infective to control Gram-positive pathogens. Int J Med Microbiol. 2010;300(6):357-62.
35. Bischoff KM, Liu S, Hughes SR, Rich JO. Fermentation of corn fiber hydrolysate to lactic acid by the moderate thermophile Bacillus coagulans. Biotechnol Lett. 2010;32(6):823-8.

36. El-Gebali S, Mistry J, Bateman A, Eddy SR, Luciani A, Potter SC, Qureshi M, Richardson LJ, Salazar GA, Smart A, et al. The Pfam protein families database in 2019. Nucleic Acids Res. 2019;47(D1):D427-D432432.

37. Kim JS, Daum MA, Jin YS, Miller MJ. Yeast derived LysA2 can control bacterial contamination in ethanol fermentation. Viruses-Basel. 2018;10:6.

38. Vollmer W, Blanot D, de Pedro MA. Peptidoglycan structure and architecture. FEMS Microbiol Rev. 2008;32(2):149-67.

39. Chapot-Chartier MP, Kulakauskas S. Cell wall structure and function in lactic acid bacteria. Microb Cell Fact. 2014;13(Suppl 1):S9.

40. Schumann P. Peptidoglycan structure. Method Microbiol. 2011;38:101-29.

41. Espaillat A, Forsmo O, El Biari K, Bjork R, Lemaitre B, Trygg J, Canada FJ, de Pedro MA, Cava F. Chemometric analysis of bacterial peptidoglycan reveals atypical modifications that empower the cell wall against predatory enzymes and fly innate immunity. J Am Chem Soc. 2016;138(29):9193-204.

42. Kotani S, Watanabe Y, Shimono T, Kinoshita F, Narita T, Kato K, Stewarttull DES, Morisaki I, Yokogawa K, Kawata S. Immunoadjuvant activities of peptidoglycan subunits from cell-walls of Staphylococcus aureus and Lactobacillus plantarum. Biken J. 1975;18(2):93-103.

43. Nagaoka M, Muto M, Nomoto K, Matuzaki T, Watanabe T, Yokokura T. Structure of polysaccharide-peptidoglycan complex from the cell-wall of Lactobacillus casei Yit9018. J Biochem-Tokyo. 1990;108(4):568-71.

44. Plapp R, Strominger JL. Biosynthesis of peptidoglycan of bacterial cell walls 18 purification and properties of L-alanyl transfer ribonucleic acid-uridine diphosphate- $N$-acetylmuramyl-pentapeptide Transferase from Lactobacillus viridescens. J Biol Chem. 1970;245(14):3675.

45. Wallinder IB, Neujahr HY. Cell wall and peptidoglycan from Lactobacillus fermenti. J Bacteriol. 1971;105(3):918.

46. Yanase $S$, Hasunuma T, Yamada R, Tanaka T, Ogino C, Fukuda H, Kondo A. Direct ethanol production from cellulosic materials at high temperature using the thermotolerant yeast Kluyveromyces marxianus displaying cellulolytic enzymes. Appl Microbiol Biot. 2010;88(1):381-8.

47. Lysons DR. Practical management of yeast: conversion of sugars to ethanol. The Alcohol Textbook. 4th ed. Nottingham: Nottingham University Press; 2003. p. 129.

48. Zheng J, Wittouck S, Salvetti E, Franz C, Harris HMB, Mattarelli P, O'Toole PW, Pot B, Vandamme P, Walter J, et al. A taxonomic note on the genus Lactobacillus: description of 23 novel genera, emended description of the genus Lactobacillus beijerinck 1901, and union of Lactobacillaceae and Leuconostocaceae. Int J Syst Evol Microbiol. 2020;70(4):2782-858.

49. Khatibi PA, Roach DR, Donovan DM, Hughes SR, Bischoff KM. Saccharomyces cerevisiae expressing bacteriophage endolysins reduce Lactobacillus contamination during fermentation. Biotechnol Biofuels. 2014;7:6.

50. Roach DR, Khatibi PA, Bischoff KM, Hughes SR, Donovan DM. >Bacteriophage-encoded lytic enzymes control growth of contaminating Lactobacillus found in fuel ethanol fermentations. Biotechnol Biofuels. 2013;6(1):20.

51. Becker SC, Foster-Frey J, Donovan DM. The phage K Iytic enzyme LysK and lysostaphin act synergistically to kill MRSA. FEMS Microbiol Lett. 2008;287(2):185-91.

52. Rich JO, Bischoff KM, Leathers TD, Anderson AM, Liu S, Skory CD. Resolving bacterial contamination of fuel ethanol fermentations with beneficial bacteria - an alternative to antibiotic treatment. Bioresour Technol. 2018:247:357-62.

53. Regulski K, Courtin P, Kulakauskas S, Chapot-Chartier MP. A novel type of peptidoglycan-binding domain highly specific for amidated D-Asp cross-bridge, identified in Lactobacillus casei bacteriophage endolysins. J Biol Chem. 2013;288(28):20416-26.

54. Roach DR, Khatibi PA, Bischoff KM, Hughes SR, Donovan DM. >>Bacteriophage-encoded lytic enzymes control growth of contaminating Lactobacillus found in fuel ethanol fermentations. Biotechnol Biofuels. 2013;6(1):20

\section{Publisher's Note}

Springer Nature remains neutral with regard to jurisdictional claims in published maps and institutional affiliations. 